WOJCIECH FAEKOWSKI

Instytut Historyczny

Uniwersytetu Warszawskiego

\title{
GRA W RYTUAŁY. DZIAŁANIA PAPIEŻA EUGENIUSZA III
}

Pierwsze lata pontyfikatu Eugeniusza III (1145-1153) miały przebieg niezwykle dramatyczny i nowy papież musiał gorączkowo zabiegać o pomoc, a przede wszystkim wykazać się niezwykłą przenikliwością w ocenie sytuacji i właściwym doborem strategii politycznej. Należało szybko określić możliwe do osiągnięcia cele i dobrać odpowiednie metody ich realizacji, a nade wszystko znaleźć takie sposoby działania, które pozwoliłyby zbudować wsparcie organizacyjne i zaplecze polityczne oraz zgromadzić potrzebne do zwycięstwa oddziały wojskowe. W papieskim otoczeniu zrozumiano niemal od razu, że konfliktu z patrycjatem nie da się rozwiązać wyłącznie siłą i nie wystarczą same kontakty dyplomatyczne i negocjacje. Dlatego sięgnięto po zabiegi socjotechniczne, które miały wykreować wizerunek papieża jako wielkiego męża stanu i przywódcy posiadającego nadrzędną pozycję w stosunku do przeciwników i monarchów z całego kontynentu. Wykorzystano wzór triumfalnego wjazdu władcy po zwycięskiej wojnie, radosnego powitania wodza po wygranej bitwie oraz stworzono nowy rytuał całowania papieskich stóp z czcią i dziękczynieniem. Otoczenie Eugeniusza III myślało w kategoriach długiego i udanego pontyfikatu. Nakazem chwili było jednak opanowanie sytuacji już w pierwszych dniach, a nawet godzinach po ogłoszeniu decyzji kardynałów.

Poprzedni papież, Lucjusz II, zmarł 15 lutego 1145 r. w wyniku ran otrzymanych podczas walk na Kapitolu, trafiony kamieniem przez obrońców, którzy odmawiali podporządkowania się jego władzy. Starannie zaplanował, a potem osobiście poprowadził atak na patrycjuszy zgromadzonych w siedzibie senatu, ponieważ wypowiedzieli mu posłuszeństwo i chcieli ustanowić republikę ${ }^{1}$. Powstałe wówczas nowe struktury administracyjne

${ }^{1}$ Obraz sytuacji przedstawił Paolo Brezzi, Roma e l’impero medioevale (774-1252), 
były całkowicie niezależne, a ich naczelnicy występowali z programem radykalnych zmian nie tylko w mieście, ale również w całym państwie papieskim. Senatorzy i patrycjat rzymski wybrali spośród drobnej arystokracji (cives possidentes) radę Pięćdziesięciu - zgodnie z jej decyzją rządy objął Giordano Pierleoni. Miał on przejąć wszystkie prerogatywy władzy od papieża, który mógł odtąd korzystać wyłącznie z wpływającej dziesięciny i prywatnych darowizn. Niemal natychmiast po ogłoszeniu tych decyzji tłum obrabował kilka pałaców kardynalskich i zażądał przekazania praw do zwierzchności nad Tivoli, które niedługo wcześniej ponownie weszło do domeny św. Piotra. Natomiast rada od razu przystąpiła do nominowania własnych urzędników i zaczęła bić monetę z napisem Senatus Populusque Romanus ${ }^{2}$.

Atak stronnictwa kurialnego na Kapitol oznaczał brak zgody na szukanie kompromisu i próbę podporządkowania miasta siłą. Ofensywa zakończyła się całkowitą klęską. Lucjusz II, który znajdował się w pierwszym szeregu walczących, został ranny i wkrótce zmarł, a jego oddziały poszły w rozsypkę. Wymogiem chwili był szybki wybór następcy, który mógłby zaprowadzić ład w szeregach zwolenników i nadać kierunek działaniom kurii i całego stronnictwa. Dlatego konklawe zostało zwołane natychmiast, jeszcze tego samego dnia. Dokonano na nim jednogłośnego wyboru Bernarda z Pizy, opata cysterskiego klasztoru św. Wincentego i Anastazego w Rzymie, wcześniej prostego mnicha w klasztorze w Clairvaux, który był tam odpowiedzialny za gromadzenie opału do pieców klasztornych ${ }^{3}$. Wybór został przeprowadzony jeszcze 15 lutego w kościele San Cesario na Palatynie, dla symbolicznego podkreślenia praw papieskich do całego Rzymu wraz ze wzgórzem kapitolińskim i sąsiadującymi dzielnicami. Głosowanie przebiegło zgodnie i bez żadnych zakłóceń, w harmonii i spokoju, mimo trwającego zagrożenia ze strony zbuntowanych obywateli ${ }^{4}$. Uroczyste wyświęcenie nowego papieża miało jednak miejsce poza miastem, w klasztorze w Farfa ${ }^{5}$. Przekazując wiadomość o początkach pontyfikatu, oficjalny żywot spisany

Bologna 1947, s. 321-329. Rozwój ruchu komun miejskich z uwzględnieniem specyfiki Rzymu w: F. Bocchi, M. Ghizzoni, R. Smurra, Storia delle città italiane. Dal tardoantico al primo Rinascimento, Torino 2002, s. 164-167 (rozdz. „Roma, un comune particolare”).

2 J.-Y.Boriaud, Histoire de Rome, Paris 2001, s. 190.

${ }^{3}$ H. Mann, The Lives of the Popes in the Middle Ages, t. 9, London 1914, s. $134 \mathrm{nn}$.

${ }^{4}$ Liber Pontificalis, wyd. L. Duchesne, t. 1-2, Paris 1886-1887 (dalej: LibPont), t. 2, s. 386, „Hic electus est ab episcopis et cardinalibus ex insperato concorditer apud monasterium sancti Cesarii, ubi omnes fratres propter metum senatorum et populi Romani consurgentis ad arma convenerant in unum".

${ }^{5}$ Il Chronicon Farfense di G. di Cantino, wyd. U. Balzani, t. 1-2, Roma 1903, t. 2, s. 321, „Eugenius III apud Farfense monasterium papa est consecratus”. 
w kancelarii laterańskiej starał się stworzyć wrażenie, że przebieg wydarzeń nie odbiegał w żadnej mierze od zwykłej procedury i cały czas postępowano zgodnie z przyjętymi zwyczajami ${ }^{6}$. Trudno było jednak ukryć klęskę i powiększającą się słabość zwolenników dotychczasowego stanu rzeczy, którzy liczyli na przywrócenie pełnej władzy papieża.

Nieco więcej szczegółów na temat przebiegu wydarzeń przekazały źródła klasztorne, które poinformowały, że wyjazd Eugeniusza III z Rzymu, w sobotę 17 lutego, trzeciego dnia po elekcji, był w istocie nocną ucieczką i dlatego konsekracja musiała odbyć się w oddalonym miejscu ${ }^{7}$.Została zorganizowana następnego dnia, 18 lutego, w pierwszą niedzielę po konklawe, od razu po przyjeździe do klasztoru. W tym czasie walki objęły całą metropolię i duża grupa stronników papieża oraz patrycjuszy spoza większości senackiej musiała także uciekać na prowincję, oddając całe miasto w ręce buntowników. Następne dziesięć miesięcy papież spędził najpierw w Narni, a potem nieco bardziej na północ, w Viterbo, by powrócić na Lateran dopiero w końcu 1145 r., tuż przed świętami Bożego Narodzenia ${ }^{8}$. Początek pontyfikatu nie był łatwy zarówno z powodu konfliktu w Rzymie, jak i ze względu na brak silnego zaplecza w kurii papieskiej i wśród poddanych.

Na wieść o wynikach konklawe Bernard, opat Clairvaux, napisał do kardynałów, że nowy następca św. Piotra jest raczej mnichem, który wybrał samotność, niż przewodnikiem po świecie doczesnym. Zwrócił uwagę na jego całkowity brak doświadczenia w zarządzaniu Kościołem i w działaniach dyplomatycznych i zapytał, czy wśród członków świętego kolegium nie było nikogo mądrego i doświadczonego, który mógłby sprostać powstałym zagrożeniom ${ }^{9}$. Wątpliwości Bernarda z Clairvaux, czy nowy papież będzie w stanie kierować biskupami i nadzorować królestwa i cesarstwa (,ad imperandum episcopis, ad regna et imperia disponenda"), zostały poddane niemal natychmiastowej weryfikacji w obliczu ostrego kryzysu ${ }^{10}$. Po ucieczce papieża senat zlikwidował urząd

${ }^{6}$ LibPont, t. 2, s. 386, ,, processit ad farfense monasterium cum domestica familia, et consecrationis gratiam in sequenti dominica et plenitudinem sui apostolatus secundum morem Ecclesie Domino auctore suscepit".

${ }^{7}$ Annales Casinenses, MGH SS, t. 19, Hannoverae 1866, s. 310, „Obiit Lucius papa, et Eugenius ordinatur, qui tertio die suae electionis nocte cum omnibus cardinalibus et episcopis Roma egressus fugit, et apud Farvensem abbatiam pontifex consecratur".

${ }^{8}$ Ibidem, ,ibique per octo menses remoratus demum vero cum Romanis paciscens, Romam reversus est". Por. Regesta Pontificum Romanorum, wyd. P. Jaffé, t. 2, Lipsiae 1888, nr 8808, wzmianka dotyczy dokumentu wydanego na Lateranie 21 XII 1145 r. Jeszcze 18 grudnia papież był w Sutri, zob. nr 8807.

${ }^{9}$ PL, t. 182, col. 426, „Sic non erat inter vos sapiens et exercitatus, cui potius ista convenirent?". Na temat stanowiska Bernarda zob. Dictionnaire d'histoire et de géographie ecclésiastiques, red. R. Aubert, Paris 1963, t. 15, col. 1349 (M.-A. Dimier).

${ }^{10} \mathrm{PL}$, t. 182, col. 426, „Ridiculum profecto videtur, pannosum homuncionem 
prefekta i ustanowił zarządcą Rzymu najwyższego urzędnika nazwanego patricius, poddając jego władzy całą administrację i sądownictwo. Władza została przejęta przez populus Romanus, który odtąd miał się cieszyć pełną wolnością. Oznaczało to przewrót, który w istocie w zasadniczy sposób ograniczał władzę świecką papieża i likwidował jego uprawnienia polityczne i gospodarcze na terenie miasta. Otton z Fryzyngi relacjonował te wydarzenia z oburzeniem, nie kryjąc obaw o los świętych miejsc, z bazyliką św. Piotra w pierwszej kolejności. Zablokowanie rzeszom pielgrzymów dostępu do kościołów i relikwii wydawało się szczególnie ważnym skutkiem trwających rozruchów i w rozumieniu kronikarza niosło dramatyczne następstwa. Zgodnie z jego relacją lud rzymski wpadł w szaleństwo i stracił wszelką miarę w swoich dążeniach i czynach, które zupełnie wymknęły się spod kontroli ${ }^{11}$. W innym miejscu, opisując początek rewolty i skuteczne działania jej przywódców, przede wszystkim Arnolda z Brescii, Otton stwierdzał z goryczą: „Chcąc przywrócić godność urzędu senatorskiego i stanu rycerskiego według starożytnych wzorów, poderwał niemal całe miasto i jego lud przeciwko papieżowi"12.

Szczegółowy opis planów Arnolda z Brescii i poparcia,jakie miał wśród rzymskich elit, przekazał Jan z Salisbury, który oskarżył go o jątrzenie przeciwko papieżowi i przypomniał o nałożonej ekskomunice. Również w tej relacji lud rzymski wybrał ogromne zło i burzył stary, dawno ustanowiony, chwalebny porządek. W opinii autora groziło to nawet herezją, która bez wątpienia musiała się łączyć z podważeniem autorytetu papieża ${ }^{13}$. Emocje zaczęły dominować wśród zwolenników obu stron i utrudniały znalezienie kompromisowego rozwiązania. Odwoływanie się do wspaniałych wzorów

assumi ad praesidendum principibus, ad imperandum episcopis, ad regna et imperia disponenda. Ridiculum, an miraculum?".

${ }^{11}$ Ottonis episcopis frisingensis chronica sive historia de duabus civitatibus, wyd. A. Hofmeister, Hannoverae-Lipsiae 1912, MGH SrG, t. [45], lib. VII, cap. 31, s. 360, „At populus Romanus cum patricio suo Iordane in furorem versus prefecturae dignitatem abolentes omnes principes ac nobiles ex civibus ad subiectionem patricii compellunt [- - ]. Ecclesiam etiam beati Petri, omnium ecclesiarum caput, incastellare sacrilege ac profanissime non metuunt. Peregrinos causa orationis advenientes ad oblationem questus gratia plagis et verberibus cogunt".

${ }_{12}$ Ottonis et Rahewini gesta Friderici I imperatoris, wyd. G. Waitz, Hannoverae-Lipsiae 1912, MGH SrG, t. [46], lib. I, cap. 28, s. 44, ,ac senatoriam dignitatem equestremque ordinem renovare ad instar antiquorum volens totam pene Urbem ac precipue populum adversus pontificem suum concitavit". Na temat przywódcy buntu zob. A. Frugoni, Arnaldo da Brescia. Nelle fonti del secolo XII, Roma 1954, zwł. s. 45-52.

${ }^{13}$ John of Salisbury, Historia Pontificalis, wyd. M. Chibnall, London 1956, s. 63, „ei [Arnoldowi] populus Romanus vicissim auxilium et consilium contra omnes homines et nominatim contra dominum papam repromisit; eum namque excommunicaverat ecclesia Romana et tamquam hereticum preceperat evitari”. 
z czasów cesarstwa rzymskiego nie mogło przesłonić ambicji senatorów zmierzających do ustanowienia niezależnych rządów i uzyskania pełnej autonomii miasta ${ }^{14}$. Oficjalnie złożona propozycja rozpoczęcia mediacji przy pomocy króla Konrada III tylko podgrzała nastroje, ponieważ senat zaoferował mu tytuł cesarski przyznawany przez siebie i lud rzymski oraz wezwał go do przybycia na stałe i wzorowania się na Konstantynie Wielkim, który ustanowił nadal aktualny, wspaniały przykład panowania ${ }^{15}$. W podtekście było to wskazanie na inne niż papieskie źródło suwerennej władzy i jej uniwersalnych prerogatyw. Kronikarz Romuald z Salerno próbował nieco usprawiedliwiać bunt, podając szczegóły trwającego wiele lat konfliktu, ale samo przywrócenie urzędów senatorskich w mieście stanowiło naruszenie uświęconego stanu rzeczy ${ }^{16}$. W krótkiej, napisanej z perspektywy kilkunastu lat rekapitulacji przebiegu wydarzeń Gerhor, prepozyt z Reichersbergu, kategorycznie stwierdził, że powstanie wybuchło przeciwko prawom boskim i dopiero papież przywrócił naturalny i oczekiwany porządek ${ }^{17}$. Bunt tlił się od dawna i dlatego nierozważna decyzja o brutalnej rozprawie z nieposłusznymi patrycjuszami tylko przyspieszyła rozwój wypadków i zradykalizowała żądania ${ }^{18}$. Znalezienie wyjścia z tej jakże trudnej i skomplikowanej sytuacji przypadło nowo wybranemu Eugeniuszowi III, który nie miał ani czasu na przygotowanie nowych planów politycznych, ani

${ }^{14}$ Analiza sytuacji i przedstawienie ideologii komun miejskich w: R. Bordowe, La società cittadina del regno d'Italia. Formazione e sviluppo delle caratteristiche urbane nei secoli XI e XII, Torino 1987, zwł. s. 101-142 (rozdz. „Libertas civitatis”). Opis fermentu w całej Italii w tym okresie w: G. Tabacco, L'Italie médiévale, Chambery 2005, s. 169-223 (rozdz. „La construction de l'État”).

${ }^{15}$ J.-Y. Boriaud, op. cit., s. 191. Odwołania do Konstantyna Wielkiego były w tym czasie częste i używane w doraźnych celach politycznych, por. De consideratione, lib. IV, cap. 6 (PL, t. 182, col. 776B), gdzie z kolei Bernard z Clairvaux wzywa papieża Eugeniusza III do naśladowania Konstantyna. Na temat szerszego kontekstu zob. H. Fuhrmann, Konstantinische Schenkung und abendländisches Kaisertum. Ein Beitrag zur Überlieferungsgeschichte des Constitutum Constantini, „Deutsches Archiv” 22, 1966, 1, s. 63-178.

${ }^{16}$ Romoaldi II. archiepiscopi Salernitani Annales (dalej: Romuald de Salerno), wyd. W. Arndt, MGH SS, t. 19, s. 424, „Non multo autem post populus Romanus contra voluntatem eiusdem papae Iordanum filium Petri Leonis in patricium promovit et senatores de novo in Urbe creavit".

17 Gerhor zmarł w 1169 r. MGH Libelli de lite imperatorum et pontificum saeculis XI et XII, t. 3, Hannoverae 1897, s. 296, w. 25-30, ,populus Romanus, quam inde gaudere volens ut dicatur populus christianus, contra leges divinas erigit potestates inordinatas, quibus qui resistunt Dei ordinationi utique non resistunt, quoniam quae a Deo sunt ordinata sunt. [- ] monente papa Eugenio, reducta in scriptum pluribus auctoritatibus aggregatis, posita est in scrinio ipsius".

${ }^{18}$ Zob. Ch. Hibbert, Histoire de Rome. Biographie d'une ville, Paris 1988, s. 94. Stopniowe i długotrwałe narastanie konfliktu podkreśla François Menant, L'Italie des communes (1100-1350), Paris 2005, s. 30-31. 
odpowiedniej ekipy doradców, która mogłaby doprowadzić chociażby do chwilowego rozejmu.

Żadna ze stron konfliktu nie przebierała w środkach, ale w początkowym okresie przewaga była po stronie patrycjatu, który kontrolował metropolię i przypuścił atak na regiony i miasta wierne papiestwu ${ }^{19}$. W tej sytuacji należało przede wszystkim wygrać kampanię w terenie, a następnie, po odcięciu dostaw żywności do Rzymu, narzucić warunki pokoju, które umożliwiłyby honorowy kompromis. W podpisanym pod koniec roku traktacie senat uzyskał akceptację swojego istnienia i działania jako niezależna instytucja, ale miał odtąd funkcjonować, opierając się na autorytecie papieża. Senatorzy od niego otrzymywali nominację, jak również swoje pensje. Urząd prefekta miasta z ramienia kurii został przywrócony, ale jego uprawnienia fiskalne i sądownicze znacznie ograniczono na korzyść instytucji komunalnych ${ }^{20}$.W rękach ludu i patrycjatu znalazła się pełnia władzy prawodawczej, prawo bicia monety oraz nadzór nad sądownictwem cywilnym. Rozporządzenia i decyzje senatu miały być zatwierdzane przez zgromadzenie obywateli każdorazowo zwoływane w tym celu na wzgórze kapitolińskie przez dzwon i hejnał trąbki. Obywatele mający czynne prawo wyborcze tworzyli parlament, który rozliczał urzędników na koniec ich kadencji ${ }^{21}$. Powołana specjalna rada miejska z siedzibą w kościele Santa Maria Aracoeli pozostawała organem pomocniczym, który ściśle współpracował z patrycjuszami ${ }^{22}$. Eugeniusz III zdołał wprawdzie utrzymać kontrolę nad kilkoma zamkami, które zyskały specjalny status (castra specialia Ecclesiae) i były zarządzane przez specjalnie wyznaczonego kurialnego urzędnika, ale władza nad miastem w praktyce przeszła w ręce przedstawicieli ludu ${ }^{23}$.

Zawarte porozumienie stało się w istocie konstytucją Rzymu, która sankcjonowała kruchy kompromis między zwalczającymi się frakcjami

${ }^{19}$ LibPont, t. 2, s. 387, „,ivitates et castra beati Petri assiduis rapinis et gravibus guerris persequi non cessabant, abutentes patientia et masuetudine pii patris et boni eorum pastoris".

${ }^{20}$ Ottonis episcopis frisingensis chronicon, lib. VII, cap. 34, „At Eugenius cum Romanis hoc tenore pacem fecit, ut patriciatus dignitatem exfestucarent et prefectum in pristinam dignitatem reciperent, senatores vero ex eius auctoritate tenerent".

${ }^{21}$ Zob. P. Brezzi, op. cit., s. 323. Por. B. Schimmelpfennig, Das Papsttum, Darmstadt 1984, s. 176.

${ }^{22}$ Przegląd ideologii komun miejskich znajdujemy w artykule: J.-C. Maire Vigueur, Justice et politique dans l'Italie communale de la seconde moitié du XIII siècle: l'exemple de Pérouse, „Comptes-rendus des séances de l'Académie des Inscriptions et Belles Lettres" 130, 1986, 2, s.312-328, zwł.325-327.

${ }^{23}$ LibPont, t. 2, s. 387, „Recuperavit Terracinum, Setium, Normam et arcem Fumonis, que a dominio beati Petri iamdiu alienata fuerant". Por. P. Toubert, Les structures du Latium médiéval. Le Latium méridional et la Sabine du IX ${ }^{e}$ siècle à la fin du XII siècle, Rome 1973, s. 1078. 
oraz przywódcami komuny i kurią papieską ${ }^{24}$. Władza papieska w mieście została znacząco ograniczona, prestiż urzędu i osoby wyraźnie obniżony, a pozycja polityczna w stosunku do europejskich monarchów bardzo osłabiona. Jedynie zręczna i skuteczna gra nowego następcy św. Piotra mogła zmienić ten obraz, ale konieczne było natychmiastowe przywrócenie utraconego autorytetu i zademonstrowanie jego prawa do kontroli nad Rzymem i jego mieszkańcami. W tym celu papież musiał powrócić do miasta, zamieszkać na Lateranie i okazać światu nienaruszoną chwałę i majestat ${ }^{25}$. Należało stworzyć publiczny przekaz o znakomitym przywódcy, który łączy skuteczność i zręczność polityczną z dominującą pozycją i najwyższym autorytetem. Dla osiągnięcia tego celu kuria sięgnęła po rytuał uroczystego wjazdu do miasta, wspaniałego powrotu władcy po zwycięstwie (adventus regis), co miało podkreślić odniesiony triumf i przywrócić zachwianą hierarchię władzy i prestiżu.

Wjazd odbył się 19 grudnia 1145 r. i przekształcił się w masowe i entuzjastyczne powitanie, które objęło znaczną część miasta. Kardynał Bozon, autor żywota Eugeniusza III, napisał z emfazą, że za sprawą Boga wielka radość opanowała całą metropolię ${ }^{26}$. Powitanie było rzeczywiście imponujące, a sprawność, z jaką zgromadzono tłumy i przygotowano wjazd, musiała zrobić wrażenie na wszystkich obserwatorach. Na całej trasie do pałacu laterańskiego licznie zebrani mieszkańcy powiewali palmowymi gałązkami głośno wyrażając swoją radość. Część obecnych została dopuszczona do ucałowania stóp i twarzy papieża. Wokół stali chorążowie z banderiami, a przy nich cały korpus urzędniczy i duże grupy Żydów, którzy również okazywali wielką radość, trzymając na widoku prawo Mojżeszowe. Zebrane duchowieństwo śpiewało psalm Benedictus qui venit in nomine Domini, co przypominało o wjeździe Chrystusa do Jerozolimy i tworzyło teologiczne uzasadnienie powitania następcy św. Piotra ${ }^{27}$. Mimo oszczędnego opisu

${ }^{24}$ Zob. F. A. Gregorovius, Historia miasta Rzymu w średniowieczu, t. 1-4, Zgorzelec 2009 (oryg. niem. 1869), tu t. 2, s. 1044-45.

${ }^{25}$ Werner Maleczek zwrócił uwagę, że Eugeniusz III ze 100 miesięcy swojego pontyfikatu spędził w Rzymie tylko 16, z tego dwa na Zatybrzu. Natomiast 52 miesiące pozostawał w różnych miejscowościach należących do patrimonium św. Piotra, idem, Rombeherrschung und Romerneuerung durch das Papsttum, w: Rom im hohen Mittelalter. Studien zu den Romvorstellungen und zur Rompolitik vom 10. bis zum 12. Jahrhundert, wyd. B. Schimmelpfennig, L. Schmugge, Sigmaringen 1992, s. 24.

${ }^{26}$ LibPont, t. 2, s. 387, „Factum est igitur Deo auctore gaudium magnum in tota urbe"; na temat Bozona zob. O. Engels, Kardinal Boso als Geschichtsschreiber, w: Konzil und Papst. Historische Beiträge zur Frage der höchsten Gewalt in der Kirche. Festgabe für H. Tühle, red.G. Schwaiger, München 1975, s. 147-168, zwł. s. 151-155. Także, Lexikon des Mittelalters, t. 2, z. 3, red. R.-H. Bautier, München 1982, col. 478-479 (W. Maleczek).

${ }^{27}$ LibPont, t. 2, s. 387, ,populi multitudo cum ramis, et ad eius vestigia frequentissime corruentes, post pedum oscula elevabantur ad oris oscula. Precedebant signiferi 
wyraźnie można dostrzec wcześniejsze, intensywne i konsekwentne przygotowania oraz skalę mobilizacji wszystkich zwolenników, którzy mieli swoją obecnością i zachowaniem potwierdzić papieskie wpływy w mieście.

Śpiewane chóralnie słowa czci i szczęścia zostały oczywiście zaczerpnięte z Biblii, gdzie pojawiają się w Psalmie 118 i w Ewangeliach. Wers psalmu wyraża nastrój wielkiej radości z okazji przybycia w imię Pańskie i zawiera błogosławieństwo dla osoby przybywającej ${ }^{28}$. Treść wersu jest dobrze dopasowana do uroczystej aranżacji wjazdu i ceremonii radosnego powitania, oddając nastrój oczekiwania i odwołując się do pragnienia, aby imię Pańskie było szczerze wielbione. Stanowi podniosłe powitanie, bardzo uroczyste w formie, które jednocześnie głosi chwałę Chrystusa i Kościoła. Natomiast następny fragment psalmu można odnieść wprost do zachowania tłumów, ponieważ przypomina o zwyczaju witania dostojnego gościa $\mathrm{z}$ gałązkami w dłoniach ${ }^{29}$. Powrót papieża przekształcał się zatem w czytelną metaforę wjazdu Chrystusa do Jerozolimy, kiedy zapłakał na losem miasta i przestrzegał przed jego upadkiem spowodowanym grzechami mieszkańców ${ }^{30}$. Odnoszący się do tych wydarzeń fragment Ewangelii był jeszcze ściślej dostosowany do sytuacji kończącego się właśnie konfliktu, ponieważ znajdujemy w nim uwagi o przywracaniu władzy prawowitemu suwerenowi. Apostołowie i mieszkańcy Jerozolimy głośno wołali: „Błogosławiony Król, który przychodzi w imię Pańskie. Pokój w niebie i chwała na wysokościach" ${ }^{31}$. Dla zgromadzonych tłumów i całej opinii publicznej władcą doczesnym był papież, który uosabiał samego Chrystusa i czerpał wzory wprost z Ewangeliii ${ }^{32}$.

Chrystus, obdarzony tytułem królewskim, określony jako najwyższy panujący, ponad wszystkimi monarchami, ustanawiający pokój na całej ziemi zgodnie ze swoimi wyrokami i własną wolą, pozostawał niedościgłym wzorem przewodnika i przywódcy politycznego. Tworzona na użytek

cum bannis, sequebantur scrinarii et iudices; Iudei quoque non deerant tante letitie, portantes in humeris suis legem Moysacam; universus etiam Romanus clerus psallebant in unum, dicentes: Benedictus qui venit in nomine Domini".

${ }^{28}$ Ps 118,26, „Błogosławiony, który przybywa w imię Pańskie! Błogosławimy wam z domu Pańskiego" (tu i delej polskojęzyczne cytaty biblijne według Biblii Tysiąclecia, wyd. 2, Poznań 1971).

${ }^{29}$ Ps 118,27, ,Zacieśnijcie pochód z gałęziami w ręku aż do rogów ołtarza”.

${ }^{30}$ Łk 19,41-44.

${ }^{31}$ Łk 19,38.

${ }^{32}$ Por. uwagi Ernsta Kantorowicza, który podkreślał znaczenie psalmu Benedictus qui venit przy tworzeniu ideowego znaczenia wjazdu Karola Wielkiego do Rzymu w 774 r., idem, The "King's Advent" and the Enigmatic Panels in the Doors of Santa Sabina, „The Art Bulletin” 24, 1944, 4, s. 217. 
publiczny analogia sugerowała, że wyłącznie namiestnik Chrystusa i następca św. Piotra ma prawo wprowadzać własne zasady i rozporządzenia nie tylko w państwie, które mu zostało powierzone, ale także we wszystkich krajach na całym kontynencie ${ }^{33}$. Skojarzenie scen wjazdu z tekstem biblijnym musiało narzucać się z całą siłą, zwłaszcza w momencie przezwyciężenia kryzysu i zaprowadzenia starego ładu. Powrót na Lateran przekształcał się w triumfalne wkroczenie do wdzięcznego miasta zgodnie $\mathrm{z}$ regułami wspaniałego adventus regis, stawał się imponującą paradą zwycięskiego wodza i uwielbianego zdobywcy ${ }^{34}$. W tym wypadku był to jednak również najwyższy kapłan i wierny naśladowca Chrystusa, który zyskiwał dzięki temu specjalne prawo do rządów i przywództwa ${ }^{35}$.

Przypomnijmy często wykorzystywany w takich sytuacjach fragment Psalmu 72, którego użył autor żywotów papieskich przy pisaniu biografii Aleksandra III, „et adorabunt eum omnes reges terre, omnes gentes servient ei" 36 . Triumf wojenny Eugeniusza III nie był bezdyskusyjny i nie przywracał natychmiast pełni autorytetu i władzy, dlatego nie można było zastosować tak jednoznacznej pochwały i wskazać wprost na ziemski wymiar jego potęgi. Niemniej jednak aranżacja powrotu do miasta oprócz sprowokowania głośnej i powszechnej radości tłumu przyjęła także formę efektownego wjazdu wodza po wygraniu wojny i miała przypominać o doczesnych celach pontyfikatu. Papież przedstawiał się jako panujący, który miał prawo decydować o losie swoich poddanych, a jednocześnie był odpowiedzialny za wszystkich chrześcijan, mieszkańców wszystkich królestw na ziemi. Chętnie przyjmował objawy uwielbienia i radości, ale przypominał o swojej odpowiedzialności za miasto i lud pozostający pod jego władzą. Jednocześnie wskazywał na nadrzędną rolę papiestwa w stosunku do wszystkich narodów, zgodnie z otrzymanym mandatem i spełnianą posługą ${ }^{37}$.

${ }^{33}$ Por. W. Ullmann, The Growth of Papal Government in Middle Ages. A Study in the Ideological Relation of Clerical to Lay Power, London 1962, s. 432-434, z tezą o niewątpliwym prawie duchowieństwa, a także w pierwszej kolejności papieża do sprawowania władzy zwierzchniej.

${ }^{34}$ LibPont, t. 2, s. 387, „Sic itaque cum magno populorum gaudio et clamore idem pontifex Lateranense palatium conscendere meruit".

${ }^{35}$ Zestawienie różnych form uroczystego powrotu władcy po zwycięstwie oraz odniesienia do literatury przedmiotu, zob.: W. Fałkowski, Adventus regis. Powrót Władysława Jagietly do Krakowa po zwycięstwie grunwaldzkim, RH, 76, 2010, s. 77-102.

${ }^{36}$ Ps. 72,11; LibPont, t. 2, s. 404.

${ }^{37}$ Dyskusję związaną z gelazjańską koncepcją rozdzielenia władzy świeckiej i duchownej oraz eksponowanie na przełomie XI i XII w. uprawnień duchowieństwa omówił G. Benson, The Gelasian Doctrine: Uses and Transformations, w: La notion d'autorité au Moyen Age. Islam, Byzance, Occident, red. G. Makdisi, D. Sourdel, J. Sourdel-Thomine, Paris 1982, s. 13-44, zwł. s. 36-37. Podobnie, ale z podkreśleniem uprawnień papiestwa, M. Pacaut, La théocratie. L'Eglise et le pouvoir au Moyen Age, Paris 1989, s. 82-86. 
Zwycięstwo nad niepokornym miastem i utrzymanie w ryzach buntowniczej komuny miejskiej miało symbolizować odniesiony wbrew wszelkim przeciwieństwom triumf wiecznej misji nad celami i ambicjami życia doczesnego. Zwróćmy uwagę na opisane oznaki czci, wśród których było całowanie stóp papieża. Był to znak najwyższego uwielbienia, a zarazem akt publicznego uznania jego zwierzchniej władzy i potwierdzenia pełnego podporządkowania ${ }^{38}$.

Wizerunek papieża wykreowany podczas wspaniałego wjazdu nie pozostawał w sprzeczności z oczekiwaniami wielu rzymskich kurialistów oraz hierarchii kościelnej, którzy chcieli widzieć w następcy św. Piotra najwyższego monarchę i pana ziemi ${ }^{39}$. Bernard z Clairvaux, mistrz i protektor Eugeniusza III, w zadedykowanym mu dziele De consideratione uznał władzę papieską za bezpośrednią emanację autorytetu Chrystusa, natomiast jego prawo do sprawowania rzeczywistych rządów i do podejmowania rozstrzygnięć politycznych rozciągał na Kościół obejmujący cały świat ${ }^{40}$. Kościół został porównany do wielkiego okrętu, a świat do ogromnego morza z licznymi statkami przedstawiającymi wspólnoty lokalne. Na podstawie otrzymanej misji papież pozostawał wikariuszem Chrystusa (vicarius Christi) i w ramach swoich obowiązków przewodził wszystkim ludom na ziemi, będąc ich nauczycielem i przewodnikiem ${ }^{41}$. Tytuł ten, który zastąpił w dok-

${ }^{38}$ Istniejące prace na temat pocałunku jako aktu symbolicznego rozróżniają wiele rodzajów tego zachowania, ale jak dotąd nie ma zestawienia i analizy rytuału całowania stóp władców, kapłanów i osób obdarzanych szczególnym szacunkiem. O rodzajach pocałunków zob. P. Moreau, Osculum, basium, suavium, , Revue de Philologie” 52, 1978, s. 87-97; W. Frijhoff, The kiss sacred and profane: reflections on a cross-cultural confrontation, w: A Cultural History of Gesture, red. J. Bremmer, H. Roodenburg, Cambridge 1991, s. 210-218. Pocałunek liturgiczny w trakcie ceremonii kościelnych analizował Rudolf Suntrup, Die Bedeutung der liturgischen Gebärden und Bewegungen in lateinischen und deutschen Auslegungen des 9. bis 13. Jahrhunderts, München 1978, s. 362-379. Zob.także H. Fichtenau, Lebensordnungen des 10. Jahrhunderts, t. 1-2, Stuttgart 1984, tu t. 1, s. 57-60. Obrzęd padania do nóg wraz z całowaniem stóp zasługuje na odrębne opracowanie. Wprowadzenie tego rytuału podczas uroczystości z udziałem Eugeniusza III nie zostało dotąd zauważone.

${ }^{39}$ Zob. idące w tym samym kierunku uwagi Waltera Ullmanna, A Short History of the Papacy in the Middle Ages, London 1974, s. 181-183.

${ }^{40}$ PL, t. 182, col. 727-808, zob. col. 752C (lib. II, cap. 8, 16), ,tibi una commissa est grandissima navis; facta ex omnibus ipsa universalis Ecclesia, toto orbe diffusa". Rozciągnięcie tej władzy na świat i sferę świecką, col. 758B, „Ita tu haeres et orbis haereditas. Si pergis usurpare et hanc, contradicit tibi qui dicit: Meus est orbis terrae et plenitudo eius". Na temat argumentacji Bernarda zob. E.T. Kennan, Antithesis and Argument in the De consideratione, w: Bernard of Clairvaux. Studies presented to Dom Jean Leclercq, red. M. B. Pennington, Washington 1973, s. 91-109, zwł. s. 96-102.

${ }^{41}$ Ibidem, „Mare enim saeculum est; naves Ecclesiae. Inde est quod altera vice instar Domini gradiens super aquas, unicum se Christi vicarium designavit, qui non uni populo, sed cunctis praesse deberet: siquidem aquae multae, populi multi”. 
trynie Bernarda wcześniejsze określenie vicarius Petri, został potraktowany jako dowód na posiadanie przez papieża niemal autorytetu Chrystusa i od razu wszedł do stałego użytku w kancelarii laterańskiej ${ }^{42}$. Zgodnie z tym rozumowaniem wikariusz Chrystusa sprawował opiekę i nadzór nad wszystkimi poddanymi, władcami i całym ludem chrześcijańskim. W ten oto sposób łączył najważniejszą część uprawnień władcy świeckiego z posługą kapłańską i posiadał pełnię władzy (plenitudo potestatis) nad Kościołami całej ziemi, co dawało mu przewagę wobec wszystkich panujących i prawo do arbitralnego rozstrzygania sporów między nimi ${ }^{43}$. Wiązało się to $\mathrm{z}$ upowszechnianym przekonaniem, że każdy, kto sprzeciwia się jego woli, nie uznaje tym samym porządku ustanowionego przez Boga ${ }^{44}$.

Tytuł monarchy jako wikariusza Chrystusa (niekiedy wikariusza samego Boga) pojawiał się przy opisach misji królewskiej i określaniu pozycji władcy wobec poddanych jako echo terminu minister Dei. W okresie karolińskim odnajdujemy go okazjonalnie w poradnikach dobrych rządów nazywanych zwierciadłami władców, które dawały przykłady właściwego postępowania i mądrych decyzji ${ }^{45}$. Nie stworzyło to jednak obowiązującej wykładni, jak należy rozumieć obowiązujący status władcy, ani nie utorowało drogi do modyfikacji oficjalnego tytułu królewskiego. Pozostawało rodzajem górnolotnego wezwania, żeby jak najskuteczniej realizować plan zbawienia według wzorów znanych z Nowego Testamentu. W przypadku listu Cathwulfa do Karola Wielkiego z 775 r. stwierdzenie o prawie króla do zastępowania Stwórcy przypominało o najwyższej odpowiedzialności monarchii i zwierzchniej roli w stosunku do duchowieństwa,

${ }^{42}$ Zob. A. Paravicini Bagliani, Il corpo del Papa, Torino 1994, s. 82-83. Także M. Maccarrone, Vicarius Christi. Storia del titolo papale, Roma 1952, s. 100-106. Por. uwagi Marcela Pacaut, L'opposition des canonistes aux doctrines politiques de saint Bernard, w: Mélanges saint Bernard, Dijon 1953, s. 188, na temat różnic w wymowie politycznej między określeniami vicarius Christi oraz vicarius Petri.

${ }^{43}$ Por. W. Maleczek, Da Innocenzo II a Innocenzo IV. Il papato del XII e XIII secolo tra „Urbs” e „Orbis”, w: Il Papato e l'Europa, red. G. de Rosa, G. Cracco, Roma 2001, s. 144, z podkreśleniem znaczenia plenitudo potestatis dla władzy sądowniczej papieży.

${ }^{44}$ PL, t. 182, col. 286C-287A, list Bernarda z Clairvaux do Mediolańczyków: „Plenitudo siquidem potestatis super universas orbis Ecclesias, singulari praerogativa apostolicae Sedi donata est. Qui igitur huic potestati resistit, Dei ordinationi resistit". Dyskusja na temat teologicznego i politycznego znaczenia traktatu została przedstawiona przez Elisabeth T. Kennan, The "De Consideratione" of St. Bernard of Clairvaux and the Papacy in the Mid-Twelfth Century: A Review of Scholarship, „Traditio” 23, 1967, s. 73-115, zwł. s. 106-112.

${ }^{45}$ Hans-Hubert Anton w pracy Fürstenspiegel und Herrscherethos in der Karolingerzeit (Bonn 1968, s. 375-377) stwierdza przesadnie, że w epoce karolińskiej tytuł minister Dei był używany wielokrotnie i pozostawał w powszechnym obiegu. Nie podzielamy tej opinii, ale problem zasługuje na osobne rozpatrzenie. 
mającego dokładnie wypełniać otrzymane od władcy zadania ${ }^{46}$. Późniejsze karolińskie zwierciadła władcy powstające w IX w. nie wychodziły poza ten wzór, przywołując go we wzniosłym tonie i uzupełniając kwiecistą argumentacją ${ }^{47}$. W każdym wypadku były to rozważania teoretyczne, które wprawdzie nawiązywały do praktyki rządzenia i przybierały formę kategorycznych postulatów, ale nie wchodziły w skład spójnej doktryny politycznej.

Tytuł vicarius Christi został później przywołany w kronice Wipona z połowy XI w. w wierszowanej przemowie koronacyjnej skierowanej do Konrada II przed udzieleniem mu sakry. Według arcybiskupa Aribo określenie to oznaczało najwyższy honor, nadrzędny w stosunku do władzy królewskiej, i najwyższy autorytet, który koniecznie należało utrzymać i umocnić niezależnie od meandrów bieżącej polityki ${ }^{48}$.W swojej odpowiedzi monarcha akcentował moralny aspekt powierzonej mu godności traktowanej jako urząd sprawowany z ramienia Chrystusa, natomiast kronikarz po raz drugi obdarzył go tym samym tytułem ${ }^{49}$. Wypowiedziana w trakcie koronacji pochwała zawierała jasno wyrażone życzenie, by panujący dorównał idealnym standardom i przyjął wynikającą z tego pełną odpowiedzialność. Wraz z koroną nowy król otrzymywał zwięzłą dyrektywę działania wyrażoną w sugestywnej i zrozumiałej formie. Była deklaracją intencji, a jedno-

${ }^{46} \mathrm{Na}$ temat listu Cathwulfa zob. W. Fałkowski, Wielki król. Ideologiczne podstawy władzy królewskiej Karola Wielkiego, Warszawa 2011, s. 147-161. Karl F. Morrison wywodził, że tytuł vicarius Dei/vicarius Christi nie przypisywał władcy żadnych szczególnych uprawnień (idem, The Two Kingdoms. Ecclesiology in Carolingian Political Thought, Princeton 1964 , s. 59 nn.). Trudno zgodzić się z tą tezą.

${ }^{47}$ Por. Sedulius Scottus, Liber de rectoribus Christianis, wyd. S. Hellmann, München 1906, cap. 19, s. 86, na temat autora i dzieła zob. wstęp do wydania, s. 4-10, także J. Strzelczyk, Iroszkoci w kulturze średniowiecznej Europy, Warszawa 1987, s. 286-297. Także Smaragdus, Via regia, PL, t. 102, col. 958B, zob. O. Eberhardt, Via regia. Der Fürstenspiegel Smaragds von St. Mihiel und seine literarische Gattung, München 1977, zwł. s. 559-569.

${ }^{48}$ Wiponis gesta Chuonradi II imperatoris, w: Die Werke Wipos, wyd. H. Bresslau, Hannover-Leipzig 1915, MGH SrG, t. [61], cap. 3, s. 22-23, „Ad summam dignitatem pervenisti, vicarius es Christi. Nemo nisi illius imitator verus est dominator; oportet, ut in hoc solio regni cogites de honore perenni". O Wiponie zob. H. Bresslau, Einleitung, w: Die Werke Wipos. Także H. Beumann, Die Historiographie des Mittelalters als Quelle für die Ideengeschichte des Königtums, „Historische Zeitschrift” 180, 1955, 3, s. 449-488, zwł. s. 468-472. Teologiczne konsekwencje wprowadzenia tytułu vicarius Dei analizuje Walter Dürig, Der theologische Ausgangspunkt der mittelalterlichen liturgischen Auffassung vom Herrscher als Vicarius Dei, „Historisches Jahrbuch” 77, 1957, s. 174-187, zwł. s. 184-187, gdzie wskazanie na związki z dyrektywą naśladowania Boga (imitatio Dei).

${ }^{49}$ Wiponis gesta Chuonardi, cap. 5, s. 26, „[rex] respiciens ad episcopos, ut vicarius Christi, christianissime respondebat". Por. F.-R. Erkens, Vicarius Christi-sacratissimus legislator - sacra majestas. Religiöse Herrschaftslegitimierung im Mittelalter, ,Zeitschrift der Savigny-Stiftung für Rechtsgeschichte. Kanonistische Abteilung” 89, 2003, s. 12-13. 
cześnie głosiła chwałę władcy. Nie weszła jednak do użytku kancelaryjnego ani nie stała się częścią obowiązującej tytulatury.

Wprowadzenie tytułu vicarius Christi do teologicznej doktryny papiestwa było w istocie przejęciem istniejącej już wcześniej argumentacji na rzecz najwyższych uprawnień królewskich. Wykorzystywanej rzadko i przede wszystkim w pismach teoretycznych, ale funkcjonującej w świadomości elit kościelnych i personelu kancelarii. Dzięki zastosowaniu tej terminologii przez kurię następca św. Piotra miał uzyskać prawo do nadzorowania wszelkich poczynań władców świeckich. „Z całego świata płyną wezwania do ciebie wraz z potwierdzeniem twojego wyjątkowego prymatu" z patosem pisał Bernard z Clairvaux do papieża, uzasadniając tezę o wyższości jego urzędu zarówno w Kościele, jak i wobec możnych tego świata ${ }^{50}$. Argumenty sakralne wskazujące na Chrystusa jako króla królów szły w parze z przekonaniem o potrzebie posiadania jednego pana, suwerennego w swoich decyzjach i dominującego nad całym chrześcijaństwem, któremu byłyby podporządkowane wszystkie godności duchowne i świeckie. Zgodnie z tezami traktatu organizacja kościelna powinna w możliwie największym stopniu przejąć funkcje państwa, powierzając nadzór nad władzą doczesną następcy św. Piotra ${ }^{51}$.

Spektakularny powrót na Lateran miał zatem odegrać znacznie większą rolę, niż tylko ułatwić odzyskanie wpływów w samym mieście. Był próbą stworzenia publicznego przekazu, w którym papież potwierdzał rolę ideowego i politycznego przywódcy całego chrześcijańskiego uniwersum ${ }^{52}$. Powitanie odwołujące się do liturgii Niedzieli Palmowej łączyło teologiczne uzasadnienie panowania na ziemi z wołaniem o nowego króla dla poddanych. Antyfona Benedictus qui venit z jednej strony pozostawała wzniosłą pochwałą dobroczyńcy, z drugiej zaś potwierdzała prośbę ludu o przyjęcie w opiekę i pod panowanie, jedyne naprawdę sprawiedliwe i zapewniające łaskę Stwórcy. Miało to stworzyć wrażenie obcowania z naprawdę skutecznym i powszechnie akceptowanym panem wszystkich chrześcijan oraz pokazać papieża w zupełnie nowym świetle. Można stwierdzić, że na wykreowany wizerunek publiczny papieża złożyły się trzy różne pomysły i zabiegi

${ }^{50}$ PL, t. 182, De consideratione, lib. III, cap. 2, 6 (col. 761A), „Appellatur de toto mundo ad te. In quidem in testimonium singularis primatus tui”. Por. I. S. Robinson, The Papacy 1073-1198. Continuity and innovation, Cambridge 1990, s. 182-183.

${ }^{51}$ Por. E. Delaruelle, L'idée de la croisade chez saint Bernard, w: Mélanges saint Bernard, s. 59 (na temat rozumienia roli Kościoła w De consideratione).

${ }^{52}$ Zob. uwagi o aktywności Kościoła w sprawach publicznych, A. Guerreau-Jalabert, L'ecclesia médiévale, une institution totale, w: Les tendances actuelles de l'histoire du Moyen Âge en France et en Allemagne, red. J.-C. Schmitt, O. G. Oexle, Paris 2002, s. 219-226. 
zastosowane w trakcie jednej ceremonii publicznej. Podniosły hymn śpiewany przez scholę przypominał teologiczne uzasadnienia papieskiego autorytetu, wprowadzając wątek chrystologiczny. Sam triumfalny wjazd do miasta (adventus) miał przekonać o zręczności i zdolnościach politycznych Eugeniusza III i skali jego zwycięstwa. Natomiast całowanie papieskich stóp było symbolicznym potwierdzeniem prymatu jego władzy i osiągniętej pozycji, a także uznaniem własnego podporządkowania.

Pierwszy okres pontyfikatu posłużył nie tylko do odrobienia strat w Rzymie, ale także do załagodzenia wcześniejszych napięć, które od lat narastały w stosunkach z królem Francji. Już w pierwszych tygodniach po konsekracji nowy papież konsekwentnie dążył do nawiązania bliskich kontaktów z Ludwikiem VII i osiągnięcia porozumienia w sprawie wspólnych przygotowań do drugiej wyprawy krzyżowej ${ }^{53}$. W kwietniu $1145 \mathrm{r}$. za pośrednictwem biskupa Arras wysłał list, w którym wychwalał władcę i udzielał mu ojcowskiego błogosławieństwa ${ }^{54}$. W następnych miesiącach korespondencja była kontynuowana i dotyczyła nie tylko spraw szczegółowych, takich jak przywrócenie biskupstwa w Tournai i załagodzenie konfliktu o posiadłości klasztoru w Vézelay, ale także przygotowań do szerokiego sojuszu, który stworzyłby ramy współpracy w Ziemi Świętej na rzecz odzyskania Edessy. Ludwik VII potrzebował sukcesu i widział w papieżu sprzymierzeńca, który mógłby wzmocnić jego pozycję w negocjacjach z królem niemieckim. Od lat trwała rywalizacja z Konradem Staufem, a także z Henrykiem II Plantagenetem o prawo do politycznego przywództwa w skali całego chrześcijańskiego świata, więc Ludwik VII bardzo zabiegał o czytelny znak wyróżniający go z grona europejskich monarchów.

Na święta Bożego Narodzenia w 1145 r., podczas uroczystego zgromadzenia całego dworu w Bourges, król oficjalnie oznajmił o swojej woli udania się do Jerozolimy i wzięcia udziału w walce z niewiernymi. Określił to jako swoje najskrytsze pragnienie i poinformował o podjętej już decyzji55.

${ }^{53}$ Por. S. Runciman, Dzieje wypraw krzyżowych, t. 1-3, Warszawa 1987 (oryg. ang. 1953-1957), tu.t. 2, s. 221-232, z obszernym przedstawieniem ogólnej sytuacji w okresie bezpośrednio poprzedzającym wyruszenie krucjaty oraz przypisaniem inicjatywy papieżowi, nie zaś Ludwikowi VII.

${ }^{54}$ Recueil des historiens des Gaules et de la France, t. 15, wyd. M.-J.-J. Brial, Paris 1808 (dalej: RHF), s. 427.

${ }^{55}$ Eudes de Deuil, La croisade de Louis VII roi de France, wyd. H. Waquet, Paris 1949, s. 21, „In Natali Domini precedenti, cum idem pius rex Bituricas curiam celebrasset, episcopis et optimatibus regni ad coronam suam generalius solito de industria convocatis, secretum cordis sui primitus". Na przebieg obrad z pewnością miał wpływ list Eugeniusza III, uroczysta bulla wysłana 1 grudnia 1145 r., w której papież zachęcał do odważnego i skutecznego działania, RHF, t. 15, s. 429-430. Yves Sassier zwrócił uwagę 
W związku z tym nałożył na poddanych dwa nowe podatki, które znacznie zwiększyły ciężary fiskalne i wywołały protesty w całym królestwie ${ }^{56}$. Najwięksi wasale odmówili płacenia, a inni stosowali zasadę biernego oporu, przekazując należności opieszale i małymi ratami. W tej sytuacji poparcie papieża było bardzo potrzebne, również żeby umocnić pozycję wewnętrzną i powstrzymać rosnące niezadowolenie ${ }^{57}$.

W tym samym czasie Eugeniusz III nie mógł uspokoić sytuacji w mieście i szukał sprzymierzeńców, żeby pognębić opozycję i zdobyć więcej swobody w swoich rządach. W ciągu całego roku 1146 senat odzyskał przewagę w Rzymie i nakazem chwili była ucieczka z Lateranu na drugą stronę Tybru do bazyliki św. Piotra, gdzie było bezpieczniej i dało się łatwiej kontrolować ruch ludności i wojska. Papieska siedziba znajdowała się w tym czasie na południe od bazyliki, w pobliżu Campo Santo Teutonico. Nowy pałac od początku był budowany jako rezydencja obronna przygotowana na odparcie oblężenia ${ }^{58}$. Wynikało to $\mathrm{z}$ rosnącego zagrożenia i znaczącego spadku poparcia wśród elit rzymskich. Agitacja antypapieska przybierała na sile i stale zyskiwała zwolenników. Eugeniusz III potrzebował wsparcia $\mathrm{w}$ walce o zachowanie panowania nad swoim państwem, a $\mathrm{z}$ drugiej strony szukał pomocy dla przeforsowania własnej wizji przebiegu wyprawy krzyżowej. Trwająca dwa lata wymiana listów i dyplomatycznych not z Ludwikiem VII stworzyła nić porozumienia i przygotowała grunt pod bezpośrednie spotkanie. Z początkiem wiosny 1147 r. papież zdecydował się wyruszyć do Francji i wziąć udział w ostatnich przygotowaniach do krucjaty. Po przejściu Alp orszak papieski skierował się w górę Rodanu i 30 marca dotarł do Dijon ${ }^{59}$. Tam doszło do spotkania z monarchą, który wyruszył z Paryża na powitanie. Niewątpliwie król chciał uczynić gest pod adresem dostojnego gościa, ale zależało mu również na rozmowach w cztery oczy, żeby ustalić zasady regencji Sugera podczas długiej nieobecności w państwie, wyjaśnić ostatnie niejasności w związku z sytuacją polityczną przed wyprawą krzyżową oraz uzgodnić ważne szczegóły przygotowywanego synodu biskupów francuskich ${ }^{60}$.

na wyraźne objawy niezadowolenia z decyzji królewskiej, które były widoczne już w Bourges (idem, Louis VII, Paris 1991, s. 145).

${ }^{56}$ M. Pacaut, Louis VII et son royaume, Paris 1964, s. 55.

${ }^{57}$ Papież wysłał jeszcze jedną bullę w sprawie krucjaty skierowaną do Ludwika VII, z dnia 1 marca 1146 r., zob. E. Caspar, Die Kreuzzugsbullen Eugens III., „Neues Archiv" 45, 1924, s. 285-305 (na s. 300-305 jest przytoczony jej tekst).

${ }^{58}$ R. Krautheimer, Rome. Profile of a city, 312-1308, Princeton 1980, s. 267-268.

${ }^{59}$ Annales Sancti Benigni Divionensis, wyd. G. Waitz, MGH SS, t. 5, Hannoverae 1844, s. 44, „Hoc anno Eugenius papa et Ludovicus rex Franciae dominica die qua cantatur Letare Ierusalem Divioni pariter fuerunt".

${ }^{60}$ Przegląd sytuacji, Y. Sassier, op. cit., s. 158-164. 
Dokładny opis sceny spotkania zadziwia niezwykłym zachowaniem z obu stron. Kronikarz zapisał, że Ludwik z daleka zobaczył zbliżającą się świtę i wtedy szybko zsiadł z konia. Podbiegł do papieża, chcąc powitać nowego Piotra, a zarazem jakby Jezusa Chrystusa i ze łzami zaczął całować jego stopę, a następnie całą postać ${ }^{61}$. Eugeniusz III w tym czasie pozostawał niewzruszony na koniu. Zgromadzony tłum zaczął wówczas głośno wołać, żeby zwrócić uwagę, iż pocałunki i gesty pokory zostały uczynione przez samego króla Francji. Wzywano papieża, żeby się zatrzymał (zapewne koń nadal wolno szedł), żeby zechciał zauważyć władcę i zwrócić się do niego ${ }^{62}$. Dla wszystkich było bowiem jasne, że albo papież powinien zsiąść z konia, albo monarcha powinien móc ponownie dosiąść swojego wierzchowca, aby obaj mogli się ucałować, jak równi. Reakcja obserwatorów świadczyła, że ich zdaniem ceremonia spotkania powinna przebiegać w nastroju powagi i z honorami należnymi obu stronom, a tymczasem przekształciła się w scenę uwielbienia i jednostronnego podporządkowania ze strony króla. $\mathrm{Na}$ podkreślenie zasługuje zarówno królewska chęć okazania pokory i najwyższego szacunku, jak i obojętna reakcja papieża. Król wybrał postawę wiernego sługi i pomocnika, który nie wahał się publicznie zademonstrować swojego oddania i poświęcenia. Natomiast papież pozostał w roli zwierzchnika chętnie przyjmującego wyrazy czci i akceptującego bez sprzeciwu gesty poddania.

Mimo zgromadzonych tłumów i jadących naprzeciw siebie strojnych orszaków gospodarz został zignorowany lub nie został rozpoznany. Jego zachowanie nie zostało właściwie zrozumiane i spotkało się z chłodnym przyjęciem. Obserwatorzy zareagowali natychmiast, głośno objaśniając sens sceny i domagając się właściwej reakcji ze strony gościa. Relacja podkreśla niezwykły szczegół królewskiego zachowania, którym było złożenie pocałunku na stopie papieża. Bez wahania ją ucałował (amplexatus est pedem) i tym samym zaznaczył swój status posłusznego i uniżonego współpracownika. W żadnym stopniu nie wzburzyło to zgromadzonych, którzy zaprotestowali wyłącznie przeciwko rażącej obojętności biskupa Rzymu. Uważając, iż doszło do nieporozumienia, wskazywali na jedyne możliwe i powszechnie oczekiwane wyjście z niezręcznej sytuacji,jakim

${ }^{61}$ Fragmentum historicum de Ludovico VII, RHF, t. 12, wyd. F. Clément, M.-J.-J. Brial, Paris 1781, s. 91, „Videns a longe Apostolicam majestatem, statim de Palefrido descendit, pedes ei festinanter, tanquam ipsi Petro Apostolico, vel etiam Jesu Christo ipsi occurit, amplexatus est pedem Apostolicum, totum deosculabatur cum lacrymis".

${ }^{62}$ Ibidem, „Apostolicus equitabat, clamant videntes: Domine, domine, Rex est ipse, recipite eum, quod super Palefridum ascendat ei, si placet, dignemini Apostolica maiestate praecipere". Scena spotkania króla z papieżem nie doczekała się dotąd analizy poza odnotowaniem spotkania i tej relacji przez M. Pacaut, Louis VII, s. 64. 
było okazanie królowi szacunku. Pocałowanie stopy miało znaczenie zarówno symboliczne, wskazując na bezwarunkowe uznanie autorytetu następcy św. Piotra, jak i polityczne, ponieważ zapowiadało poddanie się prymatowi papieża przy realizacji planów krucjaty, a także, w dalszej perspektywie, przy tworzeniu hierarchii władzy w skali kontynentu.

Na skutek reakcji otoczenia papież zrozumiał niezręczność sytuacji i widząc tak wielką pokorę władcy, zaczął płakać. Natychmiast zatrzymał się i chcąc uczcić majestat króla i własny, objął władcę łagodnym, ojcowskim uściskiem ${ }^{63}$. Tym samym błąd szybko został naprawiony, atmosfera spotkania zmieniła się w jednej chwili, ponieważ przywrócono nastrój radosnej ceremonii powitania i wyjątkowej chwili. Przytoczona przez kronikarza papieska przemowa stanowiła swoisty komentarz do wydarzeń i łączyła wszystkie elementy ojcowskiego pouczenia. Zawierała zarazem podstawowe tezy wyznaczające ramy kontaktów dyplomatycznych z najwybitniejszymi panującymi Europy. Ludwik VII został nazwany synem i potraktowany z prawdziwym przejęciem oraz dobrą wolą, która była widoczna w udzielanych naukach moralnych, w objaśnieniach bieżących wydarzeń politycznych i przypomnieniu rzeczywistej hierarchii autorytetów. W łagodnej przestrodze padło sformułowanie właśnie wchodzące do użytku w kurii, które przedstawiało papieża jako wikariusza wszechpotężnego Boga. Świadomie został podkreślony niezwykły charakter urzędu papieskiego, który zgodnie z nową doktryną kurii laterańskiej posiadał uprawnienia władzy zwierzchniej. Królowi Francji napomnień i wskazówek udzielał pełnomocnik i uprzywilejowany współpracownik Stwórcy. Okazywana w odpowiedzi pokora najlepiej świadczyła o zdolności monarchy do sprawowania rządów i zasiadania na tronie ${ }^{64}$. Umożliwiała także bliski i oparty na wyjątkowych stosunkach kontakt z ziemskim przewodnikiem, który odwiedził jego królestwo, natomiast sama wizyta była wielkim przywilejem, wyróżniającym władcę spośród wszystkich monarchów.

Wikariusz Boga (wikariusz Chrystusa) najlepiej mógł ocenić zasługi ziemskie i postawę monarchy, zwłaszcza gdy konfrontowano przedziwne

${ }^{63}$ Fragmentum historicum de Ludovico VII, „Papa tanquam sapientissimus dissimulabat, fere tanquam videns Regis humilitatem movebatur ad lacrymas; tandem stetit, eum, prout tam Apostolicam quam Regalem decuit dignitatem, benigna et paterna receptione recepit".

${ }^{64}$ Ibidem, ,te aliquantulum recipere distuli, ut omnipotentis Dei Vicario, ad tuam perpetuam gloriam et coronam, humilem te exhiberes, ut quem ab omnibus vere te cognoscentibus et de te mihi loquentibus benignum et christianissimum Regem esse intellexeram, ipso effectu cognoscerem te lumen esse aliorum in hoc mundo regnantium, gratia et virtute tibi, qui tam sublimis et praecelsus es Rex, a Deo concessae et deditae veracissimae humilitatis". 
dzieła Boże („mira opera Dei”) z nieporadnością rodzaju ludzkiego. W takiej sytuacji uniżenie władcy było cechą naturalną i potrzebną, natomiast papieska pomoc wynikająca z jego uprzywilejowanej pozycji pozostawała koniecznym warunkiem realizacji wszystkich planów i przedsięwzięć. Papież jako ojciec wszystkich chrześcijan (pater omnium Christianorum) lepiej rozumiał naturę królewskich obowiązków i mógł nauczać zarówno zwykłych poddanych, jak i wielkich tego świata. Zawarte w jego przemowie przypomnienie własnej niskiej kondycji oraz postawy królewskiego brata Henryka, który był wcześniej przez wiele lat prostym zakonnikiem, wykonującym podstawowe posługi w klasztorze, służyło podkreśleniu potrzeby okazywania prawdziwej skromności. Jednocześnie łagodny ton pouczenia pozwalał we właściwy sposób zakończyć niezręczną sytuację upokorzenia króla przy powitaniu.

Papieski tytuł przejęty z dawnej tradycji i na nowo wprowadzony przez Bernarda z Clairvaux natychmiast zrobił wielką karierę, wchodząc do użytku w kancelarii kurialnej i do protokołu ceremonii publicznych. Nie mogło to się odbyć bez wyraźnego przyzwolenia i akceptacji ze strony wszystkich współpracowników i zagranicznych partnerów, którzy od razu przyjęli określenie wikariusz Chrystusa jako najzupełniej uprawnione i naturalne ${ }^{65}$. Tym samym uznawali najwyższy autorytet papieża nie tylko w sprawach kościelnych i teologicznych, ale także w polityce i dyplomacji. W tym kontekście rytuał całowania stóp stawał się znakiem symbolicznego podporządkowania monarchy i państwa oraz wyrażał zgodę na przyznanie papieżowi rozstrzygającego głosu również w bieżącej grze politycznej. Eugeniusz III zdołał wprowadzić ceremonię wykorzystaną w czasie wjazdu do Rzymu do oficjalnego protokołu dyplomatycznego i narzucić ją jako zachowanie obowiązujące przy oficjalnych spotkaniach. Jego adventus nawiązywał do starego wzoru utrwalonego najpierw przez starannie zaaranżowane przybycie Karola Wielkiego do Rzymu w 774 r., po zwycięskiej kampanii przeciwko Longobardom, a następnie przy wjeździe króla Franków przed koronacją cesarską w 800 r. Inscenizacja powrotu Eugeniusza III nie odbiegała od innych ceremonii na cześć podziwianego wodza-zwycięzcy ${ }^{66} . \mathrm{z}$ jednym wszakże wyjątkiem, gdyż w trakcie wspaniałego

${ }^{65}$ Por. uwagi W. Ullmanna (The Papacy as an Institution of Government in the Middle Ages, w: idem, The Papacy and Political Ideas in the Middle Ages, London 1976, s. 95-96) na temat istniejącego na początku XIII w. przekonania, że wypełnianie roli Chrystusowego wikariusza świadczy o fizycznej obecności Chrystusa w ciele papieża.

${ }^{66} \mathrm{Na}$ uwagę zasługuje przeglądowy artykuł Sabine MacCormack, Change and Continuity in Late Antiquity: The Ceremony of Adventus, „Historia. Zeitschrift für Alte Geschichte" 21,1972 , s. 721-752, gdzie poddano analizie przykłady triumfalnych wjazdów cesarskich w późnej starożytności i zmian, jakie się dokonały w tym rytuale 
spektaklu wyeksponowano nowy obrzęd całowania szat i stóp bohatera. W ten sposób wyrazy wdzięczności i uwielbienia łączyły się z symboliką okazywania najwyższego szacunku i poddania, a zebrany tłum w sposób uroczysty i bardzo emocjonalny potwierdzał wyjątkowy status bohatera i przywódcy. Można przypuszczać, że od początku mieliśmy do czynienia ze świadomym testowaniem nowego rytuału, który został najpierw wprowadzony w trakcie triumfalnego powrotu na Lateran. Zastosowano go bardzo zręcznie, na oczach tłumów mieszkańców, podczas okazałej uroczystości na dużą skalę. W związku z tym ryzyko niepowodzenia było mniejsze, ponieważ atmosfera triumfu i radości towarzysząca politycznemu przesileniu sprzyjała żywiołowym zachowaniom zgromadzonych. Od tego czasu kuria starała się narzucić rytuał całowania stóp papieża jako obowiązkową część oficjalnych spotkań. Stało się to widoczne zwłaszcza za pontyfikatu Aleksandra III, kiedy wykorzystywano go wielokrotnie i w czasie ceremonii o różnej skali.

W czerwcu 1162 r. w klasztorze w Déols w pobliżu Bourges doszło do spotkania papieża z Henrykiem II Plantagenetem ${ }^{67}$. Aleksander III, podobnie jak wcześniej Eugeniusz III, musiał uciekać zaraz po konklawe i konsekracja odbyła się niemal dwa tygodnie po wyborze, 20 września 1159 r. w niewielkiej miejscowości Ninfa, na południe od Rzymu. Następne dwa lata upłynęły na rozpaczliwej walce z opozycją skupioną wokół antypapieża Wiktora IV, skutecznie wspieranego przez stronnictwo cesarskie ${ }^{68}$. Na wiosnę 1162 r., pod naciskiem zbliżającej się ofensywy cesarskiej, Aleksander III został zmuszony do osiedlenia się we Francji ${ }^{69}$. Po podróży drogą morską wylądował w Montpellier, gdzie znalazł gościnę i opiekę. Jego sytuacja była niezwykle delikatna, ponieważ musiał nie tylko neutralizować posunięcia Fryderyka Barbarossy, ale też

u schyłku tego okresu. Brak natomiast monografii przedstawiającej tę ceremonię w dłuższej perspektywie czasowej, od starożytnego Rzymu do czasów nowożytnych.

${ }^{67}$ Annales Casinenses, s. 311-312, „Alexander papa per mare ivit in Franciam, et a rege Franciae et Anglorum honorifice receptus est".

${ }^{68}$ Opis pierwszych lat pontyfikatu w: H. Mann, The Lives of the Popes, t. 10, London 1925, s. 17-55. Przedstawienie kampanii Barbarossy w tych latach znajdujemy w: F. Cardini, G. Andenna, P. Ariatta, Il Barbarossa in Lombardia, Novarra 1987, s. 86-120. Dobry przegląd przebiegu wydarzeń przedstawia Wolfgang Georgi, Friedrich Barbarossa und die auswärtigen Mächte. Studien zur Außenpolitik 1159-1180, Frankfurt a. Main 1990, s. 42-94.

${ }^{69}$ Założenia włoskiej polityki Barbarossy omawia Knut Görich, Geld und ,honor”. Friedrich Barbarossa in Italien, w: Formen und Funktionen öffentlicher Kommunikation im Mittelalter, red. G. Althoff, Stuttgart 2001, s. 177-200. Por. także, idem, Die Ehre Friedrich Barbarossas. Kommunikation, Konflikt und politisches Handeln im 12. Jahrhundert, Darmstadt 2001, s. 133-147, 214-260. 
utrzymywać poprawne stosunki z dwoma rywalizującymi władcami, Ludwikiem VII i Henrykiem II Plantagenetem ${ }^{70}$. Jesienią rozpoczął przygotowania do synodu biskupów i uważnie śledził mnożące się inicjatywy dyplomatyczne ${ }^{71}$. W tym czasie przebywał w klasztorze w Déols, dokąd 18 września 1162 r. przybył Plantagenet z zamiarem uzyskania audiencji. Został tam trzy dni, prowadząc intensywne rozmowy i obiecując natychmiastowe korzyści w zamian za zawarcie sojuszu. Pierwsze spotkanie rozpoczęło się od ucałowania przez króla papieskich stóp, a dopiero potem nastąpiła wymiana pocałunków pokoju ${ }^{72}$. W czasie powitania król przekazał kosztowne dary, by w dalszej kolejności móc ucałować oblicze papieża, który od razu odwzajemnił symboliczny gest pokoju i przyjaźni. Niemniej jednak pierwszym rytuałem, który rozpoczął całą ceremonię, było ucałowanie stóp Aleksandra III, oznaczające uznanie jego autorytetu, a także wzorową pobożność i pokorę monarchy. Król nie skorzystał z przygotowanego dla siebie krzesła i od razu padł do stóp papieża ${ }^{73}$. W istniejącej sytuacji gesty wykonane przez angielskiego monarchę oznaczały udzielenie zdecydowanego poparcia politycznego i próbę nawiązania bliskich stosunków. Jednocześnie wyrażały przekonanie o wyjątkowej władzy papieskiej nad całym światem chrześcijańskim i przyznanie prawa do arbitrażu w sporach między władcami.

Drugim przykładem zastosowania tego rytuału była audiencja z udziałem oficjalnego poselstwa arabskiego, która odbyła się już po powrocie do Rzymu z wygnania, w 1165 r. Nie mogąc odeprzeć cesarskiej ofensywy, Aleksander III rozpoczął zabiegi o pomoc ze strony władcy Sycylii, Wilhelma Złego. Jego wsparcie było niezbędne nie tylko dla powstrzymania prowadzonej z rozmachem kampanii wojennej, ale także dla zapewnienia osobistego bezpieczeństwa papieża. W trakcie gorączkowego organizowania obrony miało miejsce wydarzenie, które natchnęło optymizmem i nadzieją

${ }^{70}$ Zob. M. Pacaut, Louis VII et Alexandre III (1159-1180), „,Revue d'Histoire de l'Église de France" 39, 1953, s. 18-22. We wrześniu 1162 r. papież skierował do Ludwika VII list, w którym zapowiadał zwrócenie się do Henryka Plantageneta $\mathrm{z}$ apelem o poddanie się królowi francuskiemu, PL, t. 200, col. 168.

${ }^{71}$ Obszerna analiza ówczesnej sytuacji we Francji znajduje się w: Y. Sassier, op. cit., s. 307-330.

${ }^{72}$ LibPont, t. 2, s. 407, „In diebus illis predictus rex Anglorum dompnum Alexandrum papam apud Dolensem monasterium corporali presentia visitavit et ad eius vestigia humiliter providit; et post oscula pedum aureis oblatis muneribus, ad oscula eiusdem pontificis est receptus". M. Pacaut w swoich pracach nie wspomina o tym spotkaniu. Zob. H. Mann, The Lives of the Popes, t 10, s. 63.

${ }^{73}$ LibPont, t. 2, s. 408, „Mox in preparato sibi faldistorio sedere declinans, circa pontificis pedes in terra cum baronibus suis voluit humiliter consedere". 
całe stronnictwo kurialne. Dzięki pomocy Wilhelma przybył na Lateran poseł emira arabskiego, który uroczyście uznał wielkość i przywództwo następcy św. Piotra. Podczas publicznej ceremonii z najwyższym szacunkiem zbliżył się do niego i ucałował stopy, a następnie padł na kolana i uniżenie schylił przed nim głowę, wielbiąc Boga w jego osobie. Kancelaria laterańska nie omieszkała dokładnie opisać audiencji, kolejno wyliczając wykonywane gesty ${ }^{74}$. Tradycyjny sposób okazywania czci został uzupełniony nowym rytuałem, który podkreślał głębokie oddanie i chęć podporządkowania.Zostało to tym bardziej docenione, iż wykonał go przybysz z daleka i wyznawca islamu.

Ten sam obrzęd został wykorzystany także podczas spotkania papieża i Fryderyka Barbarossy, zorganizowanego po długich i starannych negocjacjach 24 lipca 1177 r. w Wenecji. Rozmowy miały zakończyć wieloletni konflikt i umożliwić zawarcie traktatu pokojowego, który kończyłby wojnę między papiestwem, Ligą Lombardzką i Królestwem Sycylii z jednej strony, a cesarzem i jego stronnikami z drugiej ${ }^{75}$. Aby mogło do niego dojść, Fryderyk musiał najpierw zapowiedzieć cofnięcie swojego poparcia dla nowego antypapieża Kaliksta III, papież zaś przez swoich wysłanników zniósł nałożoną na cesarza ekskomunikę. Naoczny świadek Romuald, arcybiskup Salerno, ze wzruszeniem i powagą relacjonował przebieg wydarzeń. Ceremonia miała charakter publiczny i odbywała się na centralnym placu miasta. Cesarz przybył łodzią na nabrzeże i procesjonalnie, $\mathrm{z}$ książętami i biskupami oraz całą świtą, w orszaku z licznymi chorągwiami i znakami krzyża, pieszo skierował się do papieża, który czekał na niego przed kościołem św. Marka. Aleksander III siedział otoczony biskupami i kardynałami w strojach liturgicznych, plac zaś był szczelnie wypełniony

${ }^{74}$ Ibidem, s. 404, ,quidam Sarracenorum industrius princeps cum sociis suis reverenter accessit, et deosculatis pedibus eius, fixit genua coram eo, et inclinato capite tanquam sanctum et pium christianorum deum ipsum pontificem adoravit".

${ }^{75}$ Wszechstronne omówienie panowania Fryderyka I znajdujemy w t. 40 serii Vorträge und Forschungen, Friedrich Barbarossa. Handlungsspielräume und Wirkungsweisen des staufischen Kaisers, red. A. Haverkamp, Stuttgart 1992, dla przebiegu konfliktu z papieżem zwł. J. Petersohn, Friedrich Barbarossa und Rom, s. 129-146. Ostatnia biografia przedstawiająca całe życie na szerokim tle epoki to: K. Görich, Friedrich Barbarossa. Eine Biographie, München 2011, o zjeździe w Wenecji, s. 441-460. Założenia polityki cesarza, w tym konflikt z papieżem, omawia Bernhard Töpfer, Kaiser Friedrich Barbarossa Grundlinien seiner Politik, w: Kaiser Friedrich Barbarossa. Landesausbau - Aspekte seiner Politik - Wirkung, red. E. Engel, B. Töpfer, Weimar 1994, s. 9-30, zwł.19-21. Por. M. Pacaut, Frédéric Barberousse, Paris 1967, s. 219-240. Przedstawienie rokowań pokojowych jest w: P. Munz, Frederick Barbarossa. A Study in Medieval Politics, Ithaca, N. Y. 1969, s. 325-332. Starsze prace Heinricha Appelta na temat polityki włoskiej i idei cesarskiej można znaleźć w zbiorze artykułów, Friedrich Barbarossa, red. G. Wolf, Darmstadt 1975, s. $58-82,208-244$. 
tłumem mieszkańców ${ }^{76}$. Fryderyk Barbarossa szedł przez plac, rezygnując z oznak godności cesarskiej, i chcąc uczcić Boga w osobie papieża, najpierw zdjął z siebie wspaniały płaszcz, a następnie rzucił się do jego stóp, dokonując prostracji ${ }^{77}$. Knut Görich rozróżnia między padnięciem na kolana, co oznaczałoby uznanie wyższości papieża, a całkowitym położeniem się na ziemi, które było zachowaniem nadzwyczaj pobożnym i wyrażającym głęboką pokutę ${ }^{78}$. Aleksander III ze łzami podniósł go z ziemi, ucałował i udzielił błogosławieństwa. Cały orszak zaczął donośnie śpiewać Te Deum laudamus, natomiast cesarz pochwycił papieską prawicę i wprowadził go do kościoła, gdzie otrzymał powtórne błogosławieństwo. Dopiero wtedy powrócił do swojej siedziby ${ }^{79}$. Kronikarz dokładnie opisał kolejne wydarzenia wraz ze sceną prostracji, publicznie wykonanego gestu samoponiżenia, który w tym wypadku oznaczał także koniec konfliktu politycznego i uznanie władzy papieskiej. W kronice zabrakło natomiast miejsca dla wzmianki o ucałowaniu stóp papieża ${ }^{80}$.

${ }^{76}$ Romuald de Salerno, op. cit., s. 452, „Imperator autem de navi descendens, simul cum duce, patriarcha et episcopis suis, et clero et populo Venetie, ipsum cum vexillis et crucibus processionaliter precedente, usque ad ecclesiam sancti Marci, ante cuius atrium Alexander papa cum episcopis suis et cardinalibus, cum patriarcha Aquileie, archiepiscopis et episcopis Lombardie, ecclesiastico more ornatis, honorifice residebat, pedes accessit".

${ }^{77}$ Por. uwagi o prostracji H. Fichtenau, op. cit., s. 54-56. Interesujące rozważania na temat sposobów okazywania autorytetu i potęgi przez Barbarossę przedstawił Heinz Krieg, Herrscherdarstellung in der Stauferzeit. Friedrich Barbarossa im Spiegel seiner Urkunden und der staufischen Geschichtsschreibung, Stuttgart 2003, s. 158-174. Zob. G. Althoff, Potega rytuału. Symbolika władzy w średniowieczu, Warszawa 2011 (oryg. niem. 2003), s. 110-124, zwł. s. 119. Omawiając rytuał prostracji, autor zauważa, że po Canossie, już w XII w., kończy się okres takich gestów w wykonaniu władców. Zachowanie Fryderyka Barbarossy w Wenecji, nieomawiane przez autora, skłania do przedyskutowania problemu ponownie.

${ }^{78}$ K. Görich, Friedrich Barbarossa, s. 446.

${ }^{79}$ Romuald de Salerno, op. cit., s. 452, „Cumque ad papam appropiasset, tactus divino spiritu, Deum in Alexandro venerans, imperiali dignitate postposita, reiecto pallio, ad pedes pape totum se extenso corpore inclinavit. Quem Alexander papa cum lacrymis benigne elevans, recepit in osculo et benedixit, moxque a Teotonicis Te Deum laudamus est excelsa voce cantatum. Imperator autem apprehensa pape dextera, ipsum in ecclesia introduxit, et accepta ab illo benedictione ad palatium ducis cum suis rediit".

${ }^{80}$ Spotkanie zostało omówione i zanalizowane w: K. Görich, Friedrich Barbarossa, s. 444-450. Wcześniej, z naciskiem na powstałą legendę i ikonograficzne przedstawienia sceny na placu św. Marka, K. Schreiner, Vom geschichtlichen Ereignis zum historischen Exempel. Eine denkwürdige Begegnung zwischen Kaiser Friedrich Barbarossa und Papst Alexander III. in Venedig 1177 und ihre Folgen in Geschichtsschreibung, Literatur und Kunst, w: Mittelalter - Rezeption. Ein Symposion, red. P. Wapnewski, Stuttgart 1986, s. 145-176, zob. s. 146-148, z zaznaczeniem osculum pedis. Por. również, M. Pacaut, Frédéric Barberousse, s. 241 (bez wzmianki o ucałowaniu stóp papieża). 
Zwróćmy uwagę na formę przemarszu cesarskiego orszaku, który przekształcił się w procesję, nadając spotkaniu charakter wyraźnie religijny. Podkreślały to również liturgiczne stroje papieża i skupionego wokół niego duchowieństwa. W tym kontekście akt położenia się krzyżem przed następcą św. Piotra nabierał dodatkowego znaczenia, wpisując się w sekwencję pobożnych gestów, które w tej sytuacji były całkowicie naturalne i tworzyły pożądane tło. Zachowanie Barbarossy można było zatem interpretować jako zwrócenie się do samego Boga z prośbą o litość i wybaczenie, co osłabiało wymowę polityczną i odwracało uwagę od aspektu ideologicznego i prawnego, który sugerował supremację papieża. Zauważył to kronikarz, który stwierdził, że cesarz „w osobie papieża wielbił Boga” („Deum in Alexandro venerans”). Po klęsce pod Legnano władca za wszelką cenę szukał porozumienia i dlatego nie wahał się poświęcić antypapieża, któremu cofnął poparcie, uparcie dążył do kompromisu i bez wahań zgodził się na publiczne gesty pojednania i pokory $^{81}$. Nie chciał jednak, by jego zachowanie dawało podstawy do uznania wyższości władzy papieskiej, dlatego starał się uwypuklić sakralny wymiar uroczystości ${ }^{82}$. Akt prostracji, który dodatkowo mógł być rozumiany przez obserwatorów jako wywodząca się z tradycji bizantyjskiej proskyneza, łączył znaczenie polityczne i prawne z ideowym i religijnym, co pozwalało odwrócić uwagę od niechcianej interpretacji i skierować ją na wyraźnie manifestowaną pobożność ${ }^{83}$.

${ }^{81}$ Zob. omówienie prowadzonej rozgrywki politycznej, F. Opll, Friedrich Barbarossa, Darmstadt 1998, s. 102-123 (rozdz. „Die Wende der staufischen Politik”, 1168-1178).

${ }^{82}$ Papieskie dążenia do uzyskania przewagi politycznej oraz statusu władcy nadrzędnego w konflikcie z cesarzem przedstawia M. Pacaut, Alexandre III. Étude sur la conception du pouvoir pontifical dans sa pensée et dans son œuvre, Paris 1956, zwł. s. 173-184, 240-245. K. Görich (Friedrich Barbarossa, s. 447), podkreśla, że spotkanie zaplanowano tak, by żaden z partnerów nie stracił twarzy. Zgadzamy się z tym rozumowaniem, ponieważ papież dążył do potwierdzenia swojej pozycji, a nie do upokorzenia przeciwnika. Natomiast trudno zaakceptować pogląd, że wejście Barbarossy na plac św. Marka miało formę królewskiego adventus (s. 445).

${ }^{83}$ Por. uwagi na temat obrzędu proskynezy, G. Koziol, Błaganie o przebaczenie i łaskę, Warszawa 2009 (oryg. ang. 1992), s. 128, 356, jakkolwiek niektóre podane przykłady wzbudzają pewną wątpliwość i skłaniają do polemiki, por. s.96,191. Na temat politycznego znaczenia proskynezy zob. A. Cutler, The Psalter of Basil II, w: idem, Imagery and Ideology in Byzantine Art, Aldershot 1992, s. 18-21. Ikonograficzne przedstawienia proskynezy w pałacu cesarskim w Konstantynopolu przygotowane jako instruktaż pożądanego (wymaganego) zachowania omawia Gilbert Dagron, Emperor and the Priest, Cambridge 2003 (oryg. franc. 1996), s. 99-103. Rozróżnienie między prostracją i proskynezą wymaga znajomości szczegółów zachowania. W wypadku ceremonii weneckiej jest to bardzo utrudnione. Stosowanie rytuału proskynezy w zachodnim kręgu kulturowym zasługuje na odrębne badania. 
Jeszcze tego samego wieczoru Barbarossa poprosił o zgodę na swój udział w uroczystym nabożeństwie w święto św. Jakuba, które wypadało nazajutrz. Papież chętnie wyraził zgodę i cesarz przybył w otoczeniu dworu. Po wejściu do kościoła, aby okazać swoją pokorę, przyjął rolę podrzędnego pomocnika, zdjął z siebie ceremonialny płaszcz, wziął do ręki laskę i po odsunięciu wszystkich osób otaczających celebransa sam poprowadził go do ołtarza, jakby był zwykłym kościelnym ${ }^{84}$. Dla zgromadzonych były to oznaki wzorowej skromności. W czasie mszy pozostawał wśród swoich dworzan, ale podczas kazania podszedł bliżej ambony, by móc wszystko dokładnie usłyszeć. Aleksander III kazał wówczas tłumaczyć swoje słowa na niemiecki. Natomiast podczas wyznania wiary cesarz wraz ze swoją świtą zbliżył się do papieża i padł do jego stóp, by je ucałować ${ }^{85}$. Powtarzając gest pobożności i pokory z poprzedniego dnia, utrwalał swój wizerunek gorliwego i skromnego chrześcijanina, gotowego do pomocy i współpracy.

Natomiast po zakończeniu mszy podjął papieża pod prawą rękę i odprowadził go do drzwi kościoła. Na dziedzińcu przy wsiadaniu na konia trzymał strzemię, a następnie jak prosty giermek prowadził za cugle papieskiego rumaka, zanim nie otrzymał zgody, by udać się na spoczynek $^{86}$. Zebrany tłum docenił takie postępowanie i odprowadził go do łodzi, głośno wiwatując na jego cześć. Monarcha nie stracił swojego autorytetu, zyskał zaś uznanie i podziw. Jego dwukrotna prostracja była dobrze zaplanowanym aktem samoponiżenia, który w ramach ceremonii religijnej mógł być zrozumiany jako oddanie czci Bogu i na-

${ }^{84}$ Romuald de Salerno, op. cit., s. 453, „Imperator autem, [- - ] pallium deposuit, manu virgam accepit, laicos de choro expulit et papae ad altare solemniter et processionaliter venienti viam tamquam ostiarius preparavit".

${ }^{85}$ Ibidem, ,Cumque dicto euangelio papa ascendisset pulpitum, ut alloqueretur populum, imperator accedens propius, cepit verba eius attentius auscultare. Cuius devotionem papa diligenter attendens, verba, que ipse litteratorie proferebat, fecit per patriarcham Aquileie in lingua Teotonica evidenter exponi. Finito autem sermone, et Credo in unum Deum solemniter decantato, imperator cum suis principibus ad pedes pape devotus accessit et obtulit". Koniec relacji jest niejasny, wyraźnie urwany i trudno mieć całkowitą pewność, czy cesarz ucałował stopy papieża. Wyjaśnia to informacja z Liber Pontificalis, gdzie został użyty ten sam czasownik, t. 2, s. 440, , ,apertis thesauris suis aurum ei post pedum oscula obtulit".

${ }^{86}$ Romuald de Salerno, op. cit., s. 453, „Finita autem missa, cum papa ad suum palatium vellet redire, imperator dexteram ipsius accipiens, eum usque ad portas ecclesiae satis honeste deduxit. Cumque equum suum album de more vellet ascendere, imperator ex alia parte accedens, strevam eius tenuit, et postquam equum ascendit, ipsum aliquantulum stratoris more per freni lora deduxit, quem papa benedicens, ad hospitium redire permisit”. K. Görich (Friedrich Barbarossa, s. 447) podkreśla znaczenie tego gestu (prowadzenia konia za cugle) wskazującego na uznanie Aleksandra III za prawowitego papieża. Oznaczało to cofnięcie publicznego poparcia dla antypapieża. 
miestnikowi Chrystusa na ziemi, a nie tylko jako gest polityczny, oznaczający uznanie wyższości papieża w międzynarodowej hierarchii władzy. Monarcha uznał, że nie może uchylić się od ucałowania stóp, ale uczynił wszystko, by zmienić sens tego zachowania i przedstawić go jako oznakę chrześcijańskiej prostoty i skromności. Jednocześnie usiłował ten kłopotliwy dla niego rytuał „ukryć” w długiej serii innych obrzędów.

Relacjonujący te wydarzenia kontynuator kroniki Sigeberta z Gembloux podkreślił przede wszystkim wielką pokorę cesarza, który udał się na spotkanie boso i bez wspaniałych szat wierzchnich. Zasadniczym elementem zachowania była wyraźnie okazywana bojaźń Boża i chęć podporządkowania się wskazaniom Kościoła. Barbarossa ze łzami upadł do nóg papieżowi i ucałował jego stopy ${ }^{87}$. Autor dokładnie rozdzielił wydarzenia pierwszego dnia, rozgrywające się na placu św. Marka, którym poświęcił krótką wzmiankę, od rozmów na temat traktatu pokojowego, prowadzonych według niego dzień później. Natomiast nic nie wspomniał o zachowaniu władcy podczas mszy. Znajdujemy potwierdzenie ucałowania stóp oraz wiadomość o przejściu boso, aż do papieskiego tronu. Klaus Schreiner podważył wiarygodność tego przekazu, uznając go za skorzystanie przez kronikarza ze starych wzorów królewskiej pobożności, zalecających pokutę boso $^{88}$. Mimo milczenia w tej sprawie Romualda $z$ Salerno nie wydaje się, żeby można było odrzucić tę informację z całkowitą pewnością, ponieważ Barbarossa wyraźnie szukał sposobu, by odwrócić uwagę od rytuału, którego znaczenie było dla niego naprawdę groźne. Obrzęd całowania stóp niósł w sobie przekaz o suwerennej i nadrzędnej władzy papieża, zwierzchniej wobec cesarza, i dlatego w miarę możliwości należało go „przesłonić” innymi gestami i rytuałami, które odwracały uwagę i zarazem podkreślały cnoty władcy, wyróżniając go przed Bogiem. Procesjonalne przejście z wieloma chorągwiami i krzyżami z porzuceniem wspaniałego płaszcza, odbierane również jako okazanie pogardy dla blichtru i próżności, koncentrowało uwagę na sakralnych aspektach ceremonii, a nie na jej politycznym znaczeniu.

${ }^{87}$ Sigeberti gemblacensis monachi chronica, wyd. D. L.C. Bethmann, MGH, SS, t. 6, Hannoverae 1844 , s. 416, „optimates regni cum episcopis convenientes, Fredericum imperatorem et domnum papam Alexandrum, discalciatum et regiis ornamentis nudatum, in Venetia in loco qui Altus rivus nuncupatur, adduxerunt. [- - ] Sane quam timoratum Deo, quam obedientem ecclesie et domno pape se curaverit exhibere, lacrimis pedes eius deosculando et regiis muneribus honorando magnifice demonstravit".

${ }^{88}$ Zob. K. Schreiner, Nudis pedibus. Barfüßigkeit als religiöses und politisches Ritual, w: Formen und Funktionen öffentlicher Kommunikation, s. 108-110. Por. uwagi na temat płaczu króla, M. Becher, „Cum lacrimis et gemitu”. Vom Weinen der Sieger und der Besiegten im frühen und hohen Mittelalter, w: ibidem, s. 40-43. Podobnie K. Görich (Friedrich Barbarossa, s. 446), z powołaniem się na przykład Henryka V. 
Relacja z wydarzeń w Wenecji zapisana przez kardynała Bozona w Liber Pontificalis potwierdza podany przebieg wydarzeń, jedynie wyraźniej formułując warunki zniesienia ekskomuniki i dokładniej opisując samo spotkanie. Nałożona klątwa została zdjęta dopiero po złożeniu obietnicy, iż cesarz podporządkuje się Aleksandrowi III, jako katolickiemu władcy ${ }^{89}$. Natomiast z ceremonii na placu św. Marka autor opisał w pierwszej kolejności zdjęcie płaszcza, akt prostracji, ucałowanie stóp i otrzymanie pocałunku pokoju. Następnie w nastroju radości odśpiewano Te Deum laudamus i cesarz uroczyście wprowadził papieża do kościoła, gdzie otrzymał błogosławieństwo ${ }^{90}$. Relacja jest zwięzła i precyzyjna. Również wypadki następnego dnia zostały zrelacjonowane w zgodzie z innymi źródłami. Autor starał się oddać atmosferę oczekiwania na zakończenie konfliktu i podniosłych chwil, kiedy Barbarossa dwukrotnie padał do nóg papieża, całując je nabożnie. Ofiarowany mu następnie pocałunek pokoju i przyjaźni był odpowiedzią na ten gest i jednocześnie publiczną deklaracją polityczną, która oznaczała zgodę i oznajmiała o wcześniejszych poufnych ustaleniach pokojowych ${ }^{91}$.

Ceremonia wenecka potwierdziła pełny triumf Aleksandra III, nie tylko ze względu na osiągnięty sukces militarny i polityczny, ale nade wszystko z powodu uzyskania przewagi w sporze ideowym. Cesarz uznał w tym momencie wyższość władzy papieskiej i okazał to publicznie. Posłużył do tego obrzęd wprowadzony przez Eugeniusza III, w pełni wykorzystany dopiero w latach następnych.

Ucałowanie stóp papieża stało się jednym z podstawowych rytuałów wchodzących w skład ceremoniału oficjalnych spotkań. Taki sposób uniżenia się przed namiestnikiem Chrystusa przestał być tylko gestem błagalnym, oznaczającym najwyższą pokorę i uwielbienie, ale oznajmiał także o decyzji całkowitego podporządkowania. Jednocześnie rytuał zawierał ważną treść ideową, która choć niewyrażona explicite, bez formułowania rozbudowanej i solidnie uzasadnionej tezy o wyższości władzy papieskiej była dostatecznie zrozumiała i powszechnie zauważona. Dlatego gest całowania papieskich stóp stał się jednym z podstawowych zabiegów w rywalizacji o prymat w chrześcijańskim świecie. Przesłanie o najwyższych prerogatywach następcy św. Piotra zostało zręcznie wprowadzone w szeroki obieg bez odwoływania się do

${ }^{89}$ LibPont, t. 2, s. 439 , ,post promissam quoque obedientiam venerabili pape Alexandro, tanquam catholico principi, eiusque successoribus canonice intrantibus".

${ }^{90}$ Ibidem, ,in communi visione pacis bonum expectantium, deposita clamide prostravit se in terram, et deosculatis eius tanquam primi apostolorum pedibus, vere pacis osculum sibi devotissime dedit".

${ }^{91}$ Por. uwagi o wymowie pocałunku pokoju, G. Koziol, op. cit., s. 354. 
sporów doktrynalnych i ostrych polemik politycznych. Aleksander III potrafił wykorzystać pomysł swojego poprzednika i uczynić z niego skuteczny środek w politycznej grze.

\section{Game of Rituals. The Activity of Pope Eugene III}

The onset of the pontificate of Pope Eugene III (1145) abounded with dramatic events associated with the revolt of the citizens of Rome and battles waged in the streets. The papal entourage realized that the conflict could not be resolved exclusively by resorting to force or negotiations. This was the reason for the application of socio-technical undertakings intent on creating an image of the pope as a great statesmen and leader, superior to his opponents and monarchs across the Continent. Use was made of the triumphant entry of a victorious commander and a newly created ritual of kissing papal feet with adulation and thanksgiving. The title vicarius Christi was to recall the papal right to provide protection to all Christian subjects, rulers and people. The return of Eugene III to Rome referred to the model of the triumphant adventus regis modelled on the entry of Christ to Jerusalem. At the time of the pope's arrival in Dijon, Louis VII kissed his foot, as did chosen patricians upon the papal return to the Lateran. The gesture of humility and adoration was performed by the monarch who transformed the welcome into a scene of recognition for supreme authority. From that time, the See tried to impose the ritual of kissing the pope's feet as part of the official protocol. This tendency became particularly obvious during the pontificate of Alexander III, when it was applied frequently and upon the occasion of ceremonies conducted upon various scales. The ritual took place for the first time in 1162 when Henry II Plantagenet commenced a meeting with Eugene III by kissing the pope's feet. It was repeated during an audience held at the Lateran, when an Arabian envoy first kissed the feet of Eugene III and then fell to his knees and bent his head. In 1177, after a peace treaty was signed in Venice with Fredrick I Barbarossa, kissing papal feet ceased being a mere gesture of entreaty and a sign of respect and changed into an act of subjugation.

Translated by Aleksandra Rodzińska-Chojnowska 